\title{
Cellular proliferation and vascularization in ovine fetal ovaries: effects of undernutrition and selenium in maternal diet
}

\author{
Anna T Grazul-Bilska, Joel S Caton, Wendy Arndt, Kelly Burchill, Clayton Thorson, \\ Ewa Borowczyk, Jerzy J Bilski, Dale A Redmer, Lawrence P Reynolds and Kimberly A Vonnahme \\ Department of Animal Sciences, Center for Nutrition and Pregnancy and Cell Biology Center, North Dakota State \\ University, Fargo, North Dakota 58105, USA \\ Correspondence should be addressed to A T Grazul-Bilska; Email: anna.grazul-bilska@ndsu.edu
}

\begin{abstract}
Sheep were fed a maintenance (M) diet with adequate (A) Se or high (H) Se concentration from 21 days before breeding to day 135 of pregnancy. From day 50 to day 135 of pregnancy (tissue collection day), a portion of the ewes from ASe and HSe groups were fed restricted $(\mathrm{R} ; \mathbf{6 0} \%$ of $\mathrm{M})$ diet. Fetal ovarian sections were stained for: 1$)$ the presence of proliferating cell nuclear antigen (a marker of proliferating cells) to determine the proportion of proliferating primordial follicles, or the labeling index (LI; percentage of proliferating cells) for primordial, primary, secondary and antral follicles, stromal tissues, and blood vessels; 2) factor VIII (a marker of endothelial cells) or 3) a presence of apoptotic cells/bodies. The number of proliferating primordial follicles and the LI of primordial follicles was decreased by $\mathbf{R}$ and/or HSe diets. The LI was similar for theca and granulosa cells, and for secondary or antral follicles, but was greater in secondary and antral than in primordial and primary follicles. $\mathrm{R}$ diet and/or Se affected the LI in all follicle types, in stromal tissues and blood vessels. A dense network of blood vessels was detected in the areas containing secondary to antral follicles, medulla, and hilus, but areas containing primordial follicles were poorly vascularized. The number of apoptotic cells was minimal. These results demonstrate that nutrient restriction and/or Se level in the maternal diet affected cellular proliferation in follicles, blood vessels, and stromal tissues in fetal ovaries. Thus, plane of nutrition and Se in the maternal diet may impact fetal ovarian development and function.

Reproduction (2009) 137 699-707
\end{abstract}

\section{Introduction}

Hypertrophy and hyperplasia are the major processes for tissue growth and development (Baserga 1985). The fetal ovaries represent a type of tissue that expresses high cellular proliferation (Juengel et al. 2002, Sawyer et al. 2002, Van der Hurk \& Zhao 2005). In sheep, by day 75 of pregnancy, ovaries containing primordial follicles are fully formed, and by the end of pregnancy fetal ovaries contain primordial to secondary or antral follicles (Lundy et al. 1999, McNatty et al. 2000, Erickson 2001, Juengel et al. 2002, van der Hurk \& Zhao 2005).

It has been demonstrated that several factors including $\mathrm{FSH}, \mathrm{LH}$, estrogens, activin, kit ligand, epidermal growth factor, and many others affect growth and differentiation of follicles in fetal ovaries (McNatty et al. 2000, Tanaka et al. 2001, Byskov \& Westergaard 2004, Van der Hurk \& Zhao 2005, Pepe et al. 2006). Stromal tissues and blood vessels provide the scaffold to support gonadal development, which includes cell migration, organization, differentiation, and function (Mclntush \& Smith 1998, Augustin 2000, Robinson et al. 2001). However, the process of oocyte, granulosa and theca cell, stromal tissue and blood vessel growth and/or differentiation, and their interactions during fetal folliculogenesis, are poorly understood.

In addition to the factors synthesized and secreted by fetal organs, the growth and differentiation of fetal ovaries can be affected by factors of maternal origin. It has been clearly demonstrated that environmental factors, including nutrition, can affect growth, development, and physiology in the fetal and postnatal life of mammals (Borwick et al. 1997, Wright et al. 2002, Wu et al. 2006, Barker 2007, Fowler et al. 2008). Both undernutrition and overnutrition of pregnant ewes negatively affect fetal growth and development (Redmer et al. 2004, Luther et al. 2005, 2007). In fact, cellular proliferation in fetal ovaries is regulated by numerous fetal and maternal factors including factors originating from maternal diet (Lea et al. 2006). Moreover, Se has been demonstrated to diminish cellular proliferation, neo-angiogenesis, and other cellular functions in several tissues including cancerous tissues and digestive tract (Clark et al. 1996, Ganther 1999, Combs 2001, Combs \& Lu 2001, Neville et al. 2008, Zeng \& Combs 2008). 
We hypothesized that undernutrition and level of Se in maternal diet will affect cellular proliferation in fetal ovaries. Therefore, the objective of this experiment was to determine: 1 ) if maternal dietary restriction and differing levels of Se in diet impact cellular proliferation in fetal ovarian follicles, stromal tissue and blood vessels, and 2) incidence of apoptosis and blood vessel distribution in fetal ovaries obtained from sheep in late pregnancy.

\section{Results}

Fetal weight tended $(P<0.1)$ to be lower in groups fed $R$ $\operatorname{diet}(3427 \pm 192 \mathrm{~g})$ than those fed $M \operatorname{diet}(3860 \pm 165 \mathrm{~g})$. However, levels of Se in diet did not affect fetal weight, and there were no interactions between plane of nutrition and Se levels in diet.

Dietary restriction in maternal diet affected fetal ovarian weight, which was lower $(P<0.01)$ for groups fed $R$ diet $(66 \pm 4 \mathrm{mg})$ than for those fed $M$ diet $(93 \pm 9 \mathrm{mg})$. However, levels of Se in diet did not affect fetal ovarian weight, and there were no interactions between plane of nutrition and Se levels in diet. Fetal ovarian weight in groups fed $\mathrm{R}$ diet with ASe or HSe was lower $(P<0.03)$ than in group fed $M$ diet with HSe but similar to group fed $M$ diet with ASe (Table 1).

All fetal ovaries contained primordial, primary, and secondary follicles. Presence of antral follicles was detected in $72 \%$ ovaries (23 out of 32 ovaries analyzed). Maternal diet did not have any effect on incidence of antral follicles in fetal ovaries. Proliferating cells were detected in primordial, primary, secondary, and antral follicles, in stromal tissues and blood vessels of fetal ovaries (Fig. 1A-F).

The effects of dietary restriction $(P<0.08)$ and Se $(P<0.07)$ levels, but no interaction between plane of nutrition and Se in diet, on proportion of proliferating primordial follicles were observed. In addition, the effects of dietary restriction $(P<0.08)$, but not Se or interactions between plane of nutrition and Se in diet, on the labeling index (LI) of primordial follicles were observed. The proportion of proliferating primordial follicles was lower $(P<0.08)$ in groups fed $\mathrm{R}$ diet than groups fed $M$ diet $(7.4 \pm 1.2$ vs $11.3 \pm 1.7 \%)$, and was lower $(P<0.07)$ in groups fed HSe than ASe $(7.0 \pm 1.0$ vs $10.9 \pm 1.6)$. The proportion of proliferating primordial

Table 1 Effects of maternal maintenance $(M)$ and restricted $(R)$ diet with adequate $(A)$ or high $(\mathrm{H})$ Se concentrations on weight of fetal ovaries $(\mathrm{mg})$ in sheep.

\begin{tabular}{lcc}
\hline Treatment group & Number of ewes & $\begin{array}{c}\text { Fetal ovarian weight } \\
(\mathrm{mg})\end{array}$ \\
\hline M ASe & 8 & $87 \pm 9^{\mathrm{ac}}$ \\
M HSe & 8 & $98 \pm 15^{\mathrm{ab}}$ \\
R ASe & 10 & $66 \pm 4^{\mathrm{c}}$ \\
R HSe & 6 & $66 \pm 7^{\mathrm{c}}$ \\
\hline
\end{tabular}

${ }^{\mathrm{abc}} P<0.03 ;$ Means \pm S.E.M. with different superscripts differ. follicles was greater $(P<0.05)$ in the group fed $M$ diet with ASe than in the other treatment group (Fig. 2). The LI of primordial follicles tended $(P<0.08)$ to be lower in groups fed $\mathrm{R}$ than $\mathrm{M}$ diet $(2.9 \pm 0.4$ vs $4.9 \pm 094)$. The $\mathrm{LI}$ tended $(P=0.1)$ to be greater in group fed $M$ diet with ASe than in any other group (Fig. 2).

Overall, the LI was the greatest $(P<0.001)$ in granulosa cells of secondary and antral follicles, lower in primary follicles, and the lowest in primordial follicles (19.4 \pm 0.6 and $19.5 \pm 0.6$ vs $10.4 \pm 0.4$ vs $4.6 \pm 0.5 \%$; Figs 2 and 3 ). The $\mathrm{LI}$ in granulosa and theca cells of secondary (granulosa, $21.1 \pm 0.8 \%$ vs theca, $17.8 \pm 0.7 \%$ ) and antral (granulosa, $19.4 \pm 0.8 \%$ vs theca, $19.7 \pm 1 \%$ ) follicles was similar. Therefore, data for granulosa and theca cells were combined and analyzed together within secondary and antral follicles.

For primary follicles, interactions $(P<0.02)$ between plane of nutrition and Se levels in diet on the LI were observed. The $\mathrm{LI}$ in granulosa layer of primary follicles was lower $(P<0.04)$ in the group fed $\mathrm{R}$ diet with HSe than in groups fed M diet with HSe or R diet with ASe (Fig. 3). For secondary follicles, the interactions $(P<0.09)$ between plane of nutrition and Se levels in diet and the effects of level of Se in diet $(P<0.005)$ on the $\mathrm{LI}$ were observed. The $\mathrm{LI}$ was lower $(P<0.005)$ in groups fed diet with HSe than with ASe $(17.3 \pm 0.8$ vs $21.0 \pm 0.8 \%)$. The $\mathrm{LI}$ was lower $(P<0.03)$ in the group fed $\mathrm{M}$ diet with HSe than in the groups fed M diet with ASe or fed R diet with ASe, but it was similar to group fed R diet with HSe (Fig. 3). For antral follicles, the LI was affected by the level of Se in diet, which was lower $(P<0.01)$ in groups fed with HSe than with ASe $(17.3 \pm 0.9$ vs $20.9 \pm 0.8 \%)$. The $\mathrm{LI}$ was lower $(P<0.002)$ in group fed $\mathrm{M}$ diet with HSe that in any other treatment group (Fig. 3).

For stromal tissues, interactions $(P<0.09)$ between plane of nutrition and Se levels and the effects of Se level in diet $(P<0.03)$ on the $\mathrm{LI}$ were observed. The $\mathrm{LI}$ was lower $(P<0.03)$ in groups fed a diet with $\mathrm{HSe}$ than with ASe $(3.6 \pm 0.8$ vs $6.9 \pm 1.1 \%)$. The $\mathrm{LI}$ was greater $(P<0.05)$ in the group fed $M$ diet with ASe than in any other treatment group (Fig. 4).

For blood vessels, the effects of plane of nutrition $(P<0.09)$ and Se level $(P<0.01)$ in diet on the $\mathrm{LI}$ were observed. The $\mathrm{LI}$ tended $(P<0.09)$ to be lower in groups fed $R$ than $M$ diet $(7.9 \pm 2.2$ vs $11.6 \pm 2.7 \%)$, and the $\mathrm{LI}$ was lower $(P<0.01)$ in groups fed a diet with HSe than with ASe $(6.2 \pm 1.5$ vs $13.7 \pm 0.7 \%)$. The $\mathrm{LI}$ in blood vessels was greater $(P<0.04)$ in the group fed $M$ diet with ASe than any other treatment group (Fig. 5).

In the majority of fetal ovarian tissue sections, apoptotic cells were not detected. In only a few tissue sections (5 out of 32), apoptotic cells were present occasionally in a granulosa layer or stromal tissues in fetal ovaries (Fig. 6). Apoptotic cells were also detected in ovine luteal tissues serving as a control (data not shown; see Vonnahme et al. 2006, Grazul-Bilska et al. 2008). 

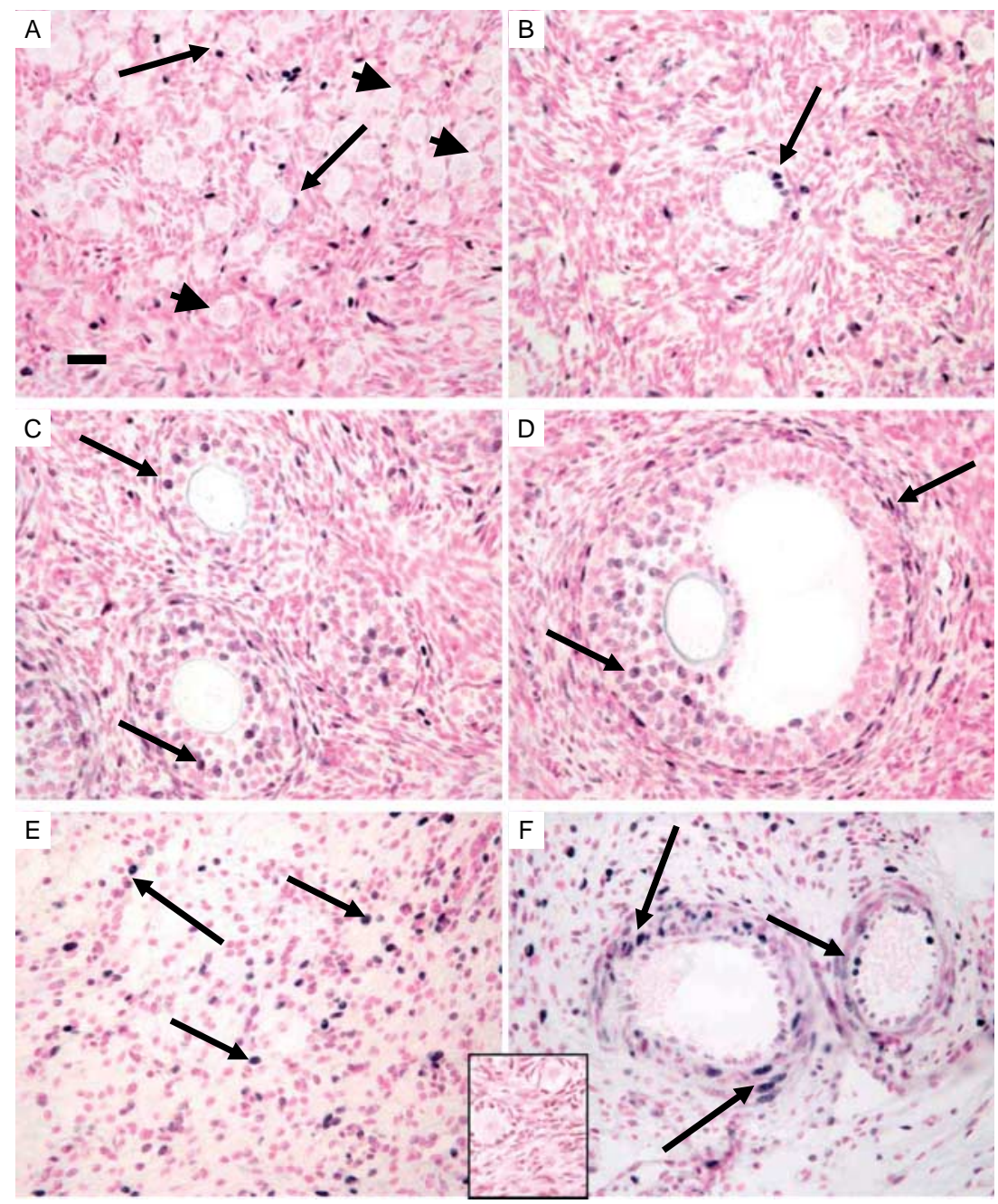

Figure 1 Representative micrographs of PCNA staining in (A) primordial, (B) primary, (C) secondary and (D) early antral follicles, $(E)$ in stromal tissues (F) and blood vessels in ovine fetal ovaries. Dark staining indicates proliferating cells (arrows), and pink staining indicates cell nuclei of non-proliferating cells. Inset represents control staining (no primary antibody). In (A), arrows indicate primordial follicles with at least one proliferating cell, and arrowheads indicate primordial follicles without visible proliferating cells. In (B), arrow indicates secondary follicle with proliferating cells. In (C, D, E, and F), arrows indicate proliferating cells in secondary follicles, antral follicle, stromal tissues, and blood vessels respectively. Bar $=25 \mu \mathrm{m}$.
Appearance of apoptotic cells in fetal ovaries was not affected by nutritional treatment.

Blood vessels marked by factor VIII staining were detected in fetal ovaries (Fig. 7). Smaller size $(\leq 30 \mu \mathrm{m})$ blood vessels were present in the areas containing

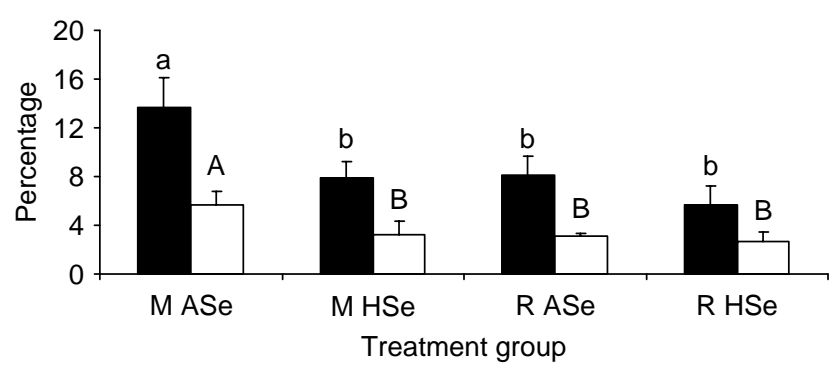

Figure 2 Proportion of proliferating primordial follicles/area (black bars) and labeling index (open bars) in primordial follicles in ovine fetal ovaries in four treatment groups fed maintenance $(M)$ or restricted $(R)$ diet with adequate $(A)$ Se or high $(H)$ Se concentration. ${ }^{a, b} P<0.05$ and ${ }^{A}, \mathrm{~B} P<0.1$; means \pm S.E.M. with different superscripts differ (unprotected $F$-test) for proportion of proliferating follicles and the LI respectively. primordial to antral follicles (Fig. 7A), and larger $(>30 \mu \mathrm{m})$ and small blood vessels were detected in ovarian medulla and hilus (Fig. 7B). For antral follicles, a network of blood vessels was detected in the theca layer (Fig. 7A). However, areas containing primordial follicles were rather poorly vascularized (Fig. 7A). The distribution of blood vessels in the ovaries seemed not to be affected by nutritional treatment.

\section{Discussion}

The results of this experiment show that both maternal dietary restrictions and level of Se in the diet differentially affected cell proliferation depending on fetal ovarian tissue compartment. This indicates that plane of nutrition and Se in the maternal diet are involved in the regulation of early folliculogenesis and ovarian tissue growth. In fact, dietary restriction tended to suppress cellular proliferation in primordial follicles and blood vessels, but high Se levels suppressed cellular proliferation in primordial, secondary, and antral follicles, 


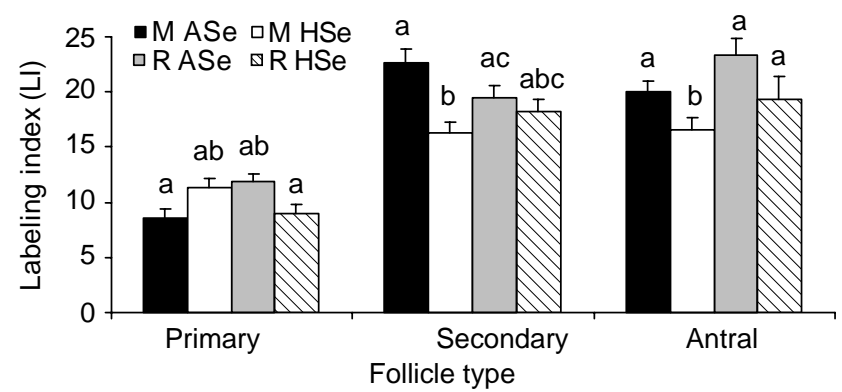

Figure 3 The labeling index in antral, secondary, and primary follicles of ovine fetal ovaries in four treatment groups fed maintenance $(M)$ or restricted $(\mathrm{R})$ diet with adequate $(\mathrm{A})$ Se or high $(\mathrm{H})$ Se concentration. a,b,c $P<0.005-0.04$; means \pm s.E.M. with different superscripts differ (unprotected $F$-test).

stromal tissues, and blood vessels. These observations are novel, since very limited information is available concerning maternal diet on cellular processes within specific compartments of fetal ovaries including developing follicles and supporting tissues such as stroma and blood vessels. In addition, these data emphasize importance of maternal diet for fetal tissue and organ growth, which is a central concept of fetal/developmental programming (Nathanielsz 2006, Barker 2007).

Dietary restrictions, but not $\mathrm{Se}$, in the maternal diet tended to affect fetal weight of the female lambs in our study. However, inconsistent results of the effects of nutrient restriction on total fetal weight (i.e., differences due to fetal sex were not reported) at the end of pregnancy in sheep have been reported, showing a decrease or no effect on fetal weight (Rae et al. 2001, Osgerby et al. 2002, Redmer et al. 2004, Lea et al. 2006, Luther et al. 2007). Similar to our findings, a lack of effect of maternal dietary restriction or environmental pollutants on ovine fetal ovarian weight has been reported by others (Rae et al. 2001, Osgerby et al. 2002, Murdoch et al. 2003, Fowler et al. 2008). Thus, the effects of maternal diet restriction on fetal growth seem to depend on the level and/or length of restriction, and the time of restriction implementation. In addition, it seems that level of Se in maternal diet composition does not affect fetal ovarian growth.

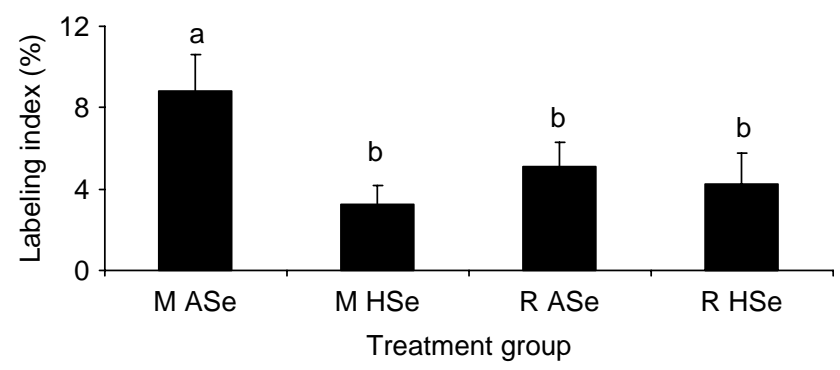

Figure 4 The labeling index in stromal tissues of ovine fetal ovaries in four treatment groups fed maintenance $(M)$ or restricted $(R)$ diet with adequate (A) Se or high (H) Se concentration. ${ }^{\mathrm{a}, \mathrm{b}} \mathrm{P}<0.05$; means \pm s.E.M. with different superscripts (unprotected $F$-test).

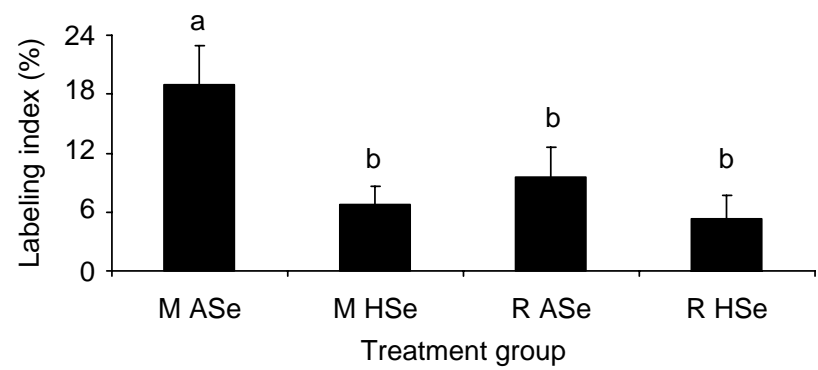

Figure 5 The labeling index in blood vessels of ovine fetal ovaries in four treatment groups fed maintenance $(M)$ or restricted $(R)$ diet with adequate $(\mathrm{A})$ Se or high $(\mathrm{H})$ Se concentration. ${ }^{\mathrm{a}, \mathrm{b}} \mathrm{P}<0.001$; means \pm S.E.M. with different superscripts differ (unprotected $F$-test).

By the end of pregnancy, fetal ovaries may contain all types of follicles including primordial, primary, secondary, and antral follicles, as observed in this and other studies on sheep and cattle (Wandji et al. 1992, Lundy et al. 1999, Bodensteiner et al. 2000, Rae et al. 2001). Growth and development of fetal ovaries is regulated by numerous factors of fetal and maternal origin including $\mathrm{FSH}, \mathrm{LH}$, estrogens, activin, c-kit and its ligand stem cell factor, enzymes controlling steroidogenesis, growth differentiation factor 9, epidermal growth factor, and many others (McNatty et al. 2000, Tanaka et al. 2001, Juengel et al. 2002, Sawyer et al. 2002, Byskov \& Westergaard 2004, Van der Hurk \& Zhao 2005, Pepe et al. 2006). Since we rarely detected apoptotic cells and atretic follicles in fetal ovaries, it seems that by the end of pregnancy, selected ovarian compartments are rather in the growing phase, and the apoptotic process is minimal. In fact, our observations are in agreement with previously published data, demonstrating very low apoptosis in ovine fetal ovaries on day 99 of pregnancy, but enhanced apoptosis in the earlier stages (days 58-73)

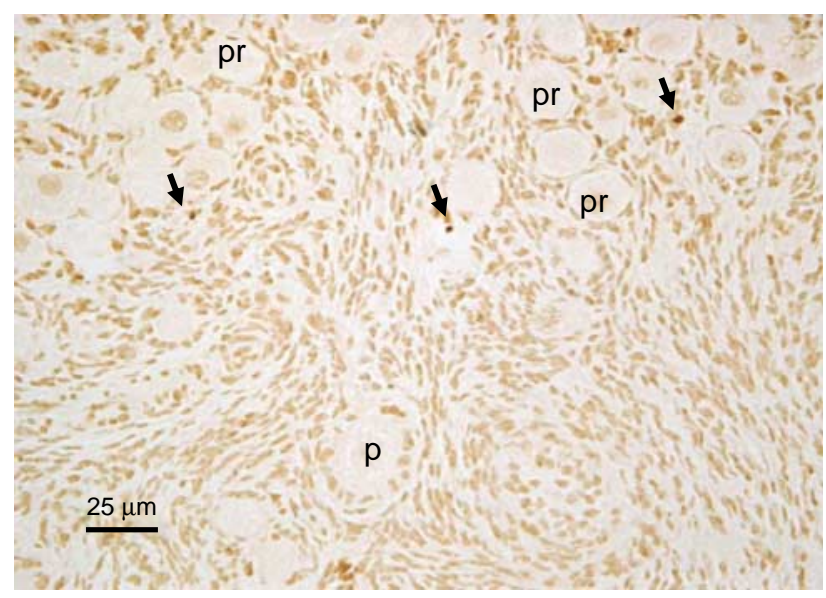

Figure 6 Representative micrograph of TUNEL staining in ovine fetal ovaries. Arrows indicate apoptotic cells/bodies (dark brown). Control sections did not show any positive staining (not shown because they were similar to unstained areas shown in this micrograph). Note numerous primordial (pr) and a few primary (p) follicles in this section. Bar $=25 \mu \mathrm{m}$. 

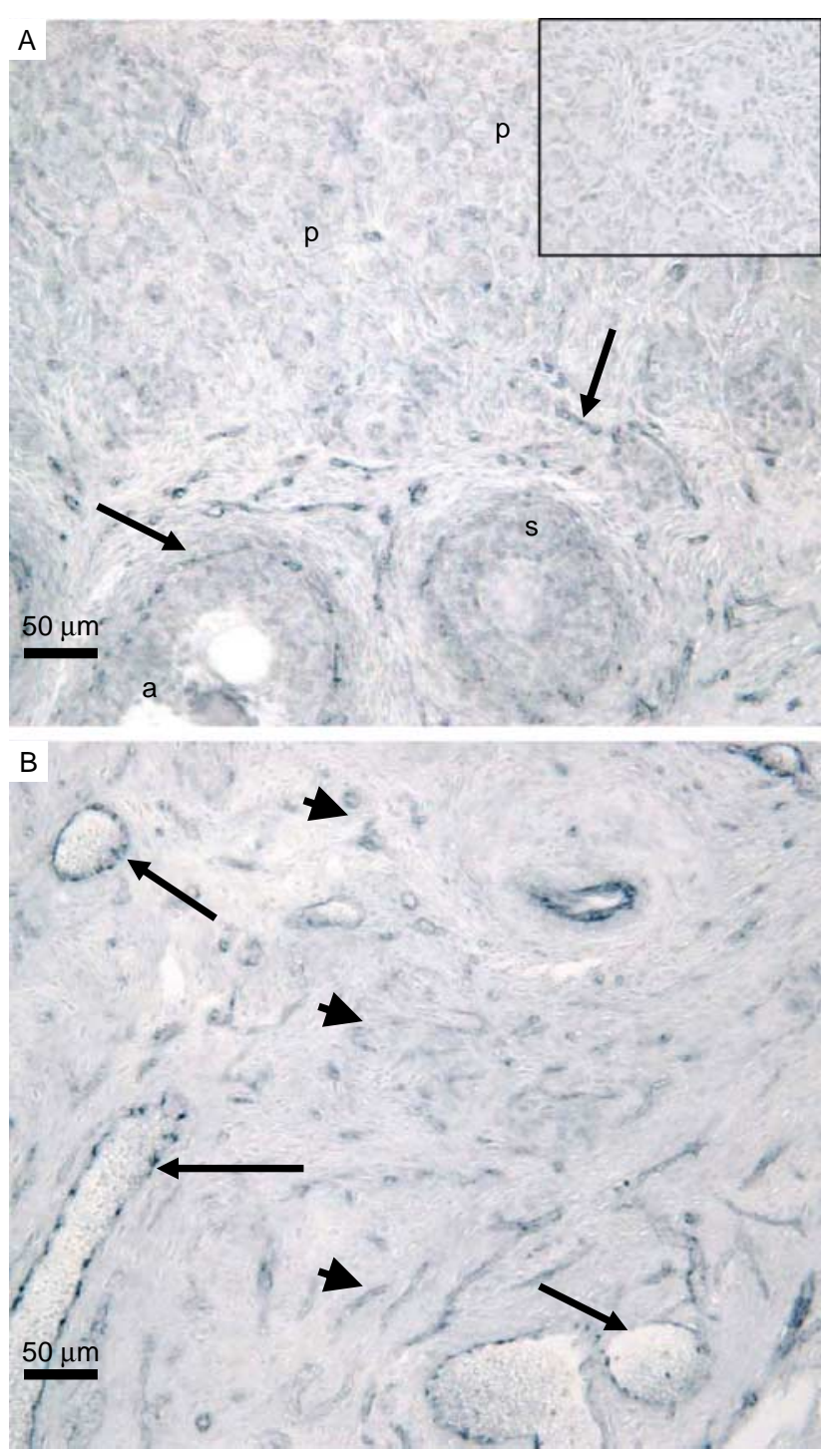

Figure 7 Representative micrograph of factor VIII staining (black color) in ovine fetal ovaries in the areas containing primordial (p), secondary (s), and antral (a) follicles (A), and in ovarian medulla (B). Inset represents control staining (no primary antibody). Note in (A), poor staining in the area containing primordial follicles, and a dense network of blood vessels (arrows) in theca layer of secondary and antral follicles, and stromal tissues. Note in (B), presence of smaller (arrowheads) and large (arrows) blood vessels. Bar $=50 \mu \mathrm{m}$.

of pregnancy (Murdoch et al. 2003, Qi et al. 2008). Although, altered expression of genes $B A X$ and MCL1, which are associated with apoptosis, in fetal ovaries on day 110 of pregnancy has been reported for underfed sheep, it is unclear whether changes in gene expression were accompanied by the appearance of apoptotic cells/bodies (Lea et al. 2006). Thus, these data indicate that apoptosis in fetal ovaries is negligible during late pregnancy.

In our study, $8-13 \%$ of primordial follicles had at least one granulosa cell that stained positively for proliferating cell nuclear antigen (PCNA). By contrast,
Lundy et al. (1999) demonstrated that $98.7 \%$ primordial follicles contained at least one proliferating granulosa cell in fetal ovaries on day 135 of gestation in sheep. These differences are likely owing to different techniques used to determine the proportion of proliferating cells even though both studies used PCNA as a marker of proliferating cells. We used $5 \mu \mathrm{m}$ of histological sections to determine differences in proportion of proliferating primordial follicles in between nutritional treatments. However, Lundy et al. (1999) used a nucleator technique to determine a proportion of proliferating follicles within a follicle type, which allowed for determination of the absolute number of granulosa cells in the individual follicle.

The present study demonstrated that the LI was lower in primordial than primary follicles, and than in secondary and antral follicles (5 vs 10 vs 19\%). Similar to our study, the LI was lower in primary follicles than secondary and antral follicles in adult rat ovaries (Gaytan et al. 1996). Since a longer period of time is required for a new growing follicle to reach the preantral stage than for a transition from the preantral stage to antral follicle (Gougeon 2004), we hypothesize that differences in the $\mathrm{LI}$ in follicle types may reflect the timing of growth from primordial to primary, from primary to secondary follicle stage, or from secondary to antral follicle stage. However, this subject requires additional study, since very little information is available concerning the timing of follicular growth in fetal ovaries.

The proliferation in granulosa and theca cells of antral fetal follicles $(17-20 \%)$ was within a range of $\mathrm{LI}$ $(17-22 \%)$ reported for small follicles from adult ovine ovaries (Jablonka-Shariff et al. 1994, 1996). This indicates that cellular proliferation within small antral follicles remains at similar level in fetal ovaries and ovaries from adult animals. In addition, the $\mathrm{LI}$ in stromal cells (3-9\%) and in blood vessels (9-20\%) were also very high. These great levels of cellular proliferation clearly demonstrate that growth of ovarian follicles is accompanied by growth of surrounding stromal tissues and angiogenesis in fetal ovaries at the end of pregnancy. In addition to providing the scaffold for growing follicles and blood vessels, stromal tissues are the source of matrix metalloproteinases and tissue inhibitors, which likely play a role in fetal gonadal development (Robinson et al. 2001). Stromal tissues also express estrogen, androgen, and progesterone receptors, which are likely involved in the regulation of fetal ovarian growth (Juengel et al. 2002). Vasculogenesis and angiogenesis, marked in this study with high proliferation in blood vessels and a dense network of blood vessels in medulla, hilus, and areas containing primordial to antral follicles are critical for supporting fetal organ growth (Augustin 2000). In addition, vascular endothelial growth factor protein, the potent angiogenic factor, is expressed in ovine fetal ovaries (AT Grazul-Bilska, unpublished observations). Although angiogenesis in adult ovaries 
has been studied extensively (Redmer \& Reynolds 1996, Grazul-Bilska et al. 2001, Fraser 2006), little is known about the angiogenic process in fetal ovaries, and therefore it needs further investigation. Nevertheless, a high density of blood vessels in ovarian medulla and hilus and the high proliferation in blood vessels and stromal tissues observed in this study indicates that fetal ovaries are quickly growing and differentiating. In fact, it seems that by the end of pregnancy, fetal ovaries are approaching a very fast growth stage, as ovarian weight increases more than 10-fold (from $\sim 80 \mathrm{mg}$ to $1 \mathrm{~g}$ ), while offspring weight only increases 3 -fold (from $\sim 3.5$ to $10 \mathrm{~kg}$ ) from day 135 of gestation to day 20 post partum (AT Grazul-Bilska, KA Vonnahme \& JS Caton, unpublished observations). Thus, it is reasonable to postulate that the high cellular proliferation in stroma and blood vessels observed in this study is critical for ovarian growth support. Moreover, a complex vascular network in mouse fetal ovaries has been recently described by Bullejos et al. (2002), which emphasizes the importance of blood supply to developing organs. Cellular proliferation in stromal tissues and blood vessels in fetal ovaries is likely controlled by growth and other factors. However, very little information is available concerning the expression and function of growth factors in fetal ovaries (McNatty et al. 2000), and the mechanism of regulation of fetal ovarian growth remains to be elucidated.

The present results clearly demonstrate that maternal diet affects cellular proliferation in fetal ovaries. A similar pattern of cellular proliferation decrease in primordial, secondary or antral follicles, stromal tissues and blood vessels was observed in groups fed $\mathrm{R}$ diet or in groups fed high Se comparing with groups fed $M$ diet with ASe in our study. However, differential effects of maternal diet on cellular proliferation in follicle types (e.g., primary versus secondary or antral) were observed in this study. These differences are likely due to a specific stage of follicular development regulation by factors controlling ovarian growth and function (McNatty et al. 2000, Erickson 2001, Sawyer et al. 2002, Byskov \& Westergaard 2004, van der Hurk \& Zhao 2005). In fact, the diverse effects of maternal diet on ovine fetal ovaries including ovarian weight, delayed ovarian growth and development, and altered ovarian cell proliferation and apoptosis have been reported by others (Borwick et al. 1997, Rae et al. 2001, Osgerby et al. 2002, Da Silva et al. 2002, 2003). In addition, maternal undernutrition has been demonstrated to reduce the number of follicles beyond the primordial stage in sheep (Rae et al. 2001). This may be associated with reduced cellular proliferations in primordial follicles observed in our study, which likely progressed at slower rates to primary and secondary follicle stages in underfed animals compared with normally fed ones.

In contrast to our observations, Lea et al. (2006) reported enhanced cellular proliferation in the granulosa layer of fetal follicles on day 110 of gestation in underfed sheep. In addition, undernutrition did not change cellular proliferation in primordial follicles (Lea et al. 2006). These differences are likely due to the different lengths of nutritional restriction and different gestational time points for tissue collection.

In our study, high Se in the maternal diet decreased cellular proliferation in primordial, secondary, and antral follicles, stromal tissues and blood vessels. Interestingly, high Se in the maternal diet also decreased jejunal proliferation in female and male fetuses in a similar study (Carlson et al. 2008). In fact, it has been demonstrated that $\mathrm{Se}$ is involved in the regulation of cell proliferation (Zeng 2002) and angiogenesis inhibition in mammary cancer (Jiang et al. 1999). Furthermore, high Se concentration can decrease cell proliferation through inhibition of DNA synthesis and induction of apoptosis (Salbe et al. 1990, Yeh et al. 2006, Zeng \& Combs 2008). Because we rarely detected apoptotic cells in fetal ovaries in this study, we hypothesize that high Se in the maternal diet suppresses cell proliferation through affecting DNA synthesis and cell cycle events. However, additional studies should be undertaken at the cellular and molecular levels to determine the mechanism of Se regulation of cell proliferation in fetal ovaries.

The role of Se in regulation of ovarian function in the fetus is unclear. However, for adult ovaries in animal models, it has been demonstrated that Se may modulate granulosa cell proliferation and estradiol- $17 \beta$ synthesis in vitro, and Se administration may affect the ovulation process, implantation, and the number of live embryos (Parshad 1999, Basini \& Tamanini 2000).

We have clearly demonstrated that maternal diet affected fetal ovarian function marked in this study by changes in cellular proliferation. In fact, the effects of maternal diet and other environmental factors on fetal and postnatal organ growth and function have been investigated for several models including humans (Rhind et al. 2003, Redmer et al. 2004, Luther et al. 2005, Barker 2007, Gardner et al. 2008). It has been demonstrated that environmental factors, including maternal diet composition, affect fetal development through many different mechanisms including alternations of gene expression or changes in organ structure and physiology (Rhind et al. 2003). However, the mechanism of the effects of undernutrition and Se in the maternal diet on fetal ovarian function remains to be elucidated.

In summary, maternal dietary restriction and/or a high level of Se in the diet decreased cell proliferation in primordial, secondary and/or antral follicles, stromal cells, and blood vessels in fetal ovaries. Moreover, the LI was greater in secondary and antral than in primordial and primary follicles, and the LI was similar for granulosa and theca cells. Thus, dietary restriction and Se in the maternal diet affect fetal ovarian growth at the end of pregnancy. Furthermore, apoptosis was minimal and a 
dense network of blood vessels was present in fetal ovaries by the end of pregnancy. The results of this study will help us to understand the role of maternal dietary restrictions and Se level in diet in regulation of cell proliferation in fetal tissues and how maternal diet may affect growing tissues. In addition, these results emphasize importance of vascularization in folliculogenesis and ovarian growth. Thus, maternal diet may impact fetal and likely postnatal/adult ovarian development and function, emphasizing the importance of maternal diet on reproductive and overall health of the offspring. On the other hand, it is currently unknown whether changes in fetal ovaries at the cellular level induced by maternal factors may affect fertility of the offspring. Since very limited and inconclusive data are available concerning maternal effects on offspring fertility (Gardner et al. 2008), further investigation is required.

\section{Materials and Methods}

\section{Animals and treatments}

The Institutional Animal Care and Use Committee at NDSU approved all animal procedures in this study. Animal feeding, maintenance, and management are described in detail by Reed et al. (2007). Following breeding, ewes were assigned randomly to either an adequate $(\mathrm{A})$ or high $(\mathrm{H})$ dietary Se treatment. Ewes were pen-fed a basal diet $(2.04 \mathrm{~kg} / \mathrm{ewe}$ per day) that contained (dry matter basis) $47 \%$ alfalfa hay, $20 \%$ corn, $20 \%$ sugarbeet pulp pellets, $8 \%$ malt barley straw, and $5 \%$ concentrated separator byproduct. In addition to the basal diet, ewes assigned to the ASe treatment were fed $100 \mathrm{~g} /$ day of a control pellet that was balanced to contain 0.30 p.p.m. Se ( $6 \mu \mathrm{g} / \mathrm{kg}$ body weight), whereas HSe ewes were fed $100 \mathrm{~g} /$ day of a high-Se pellet balanced to contain 47.5 p.p.m. Se (80 $\mu \mathrm{g} /$ $\mathrm{kg}$ body weight), provided as Se-enriched yeast (Sel-Plex, Alltech, Nicholasville, KY, USA). The control (ASe) and HSe pellets were formulated using similar ingredients to maintain similar concentrations of metabolizable energy (ME), crude protein, acid detergent fiber, neutral detergent fiber, $\mathrm{Ca}$, and $\mathrm{P}$. Selenium-enriched yeast replaced soybean meal and partially replaced ground corn relative to the control pellet. The approach by which dietary Se was supplemented to pregnant, primigravid ewes has been used previously by our laboratory (Reed et al. 2007, Carlson et al. 2008).

On day 50 of gestation, ewes within each Se treatment were stratified by average breeding date and assigned to one of two distinct plane of nutrition treatments. The ewes were offered diets that were balanced to meet either 100\% (maintenance $(\mathrm{M}))$ or $60 \%$ (restricted $(\mathrm{R})$ ) of predicted ME requirements of pregnant ewe lambs (NRC 1985). The plane of nutrition treatments were applied from day 50 to 135 of pregnancy, which resulted in four distinct treatment combinations designated by the following; $M$ ASe ( $n=8$ ewes), $M$ HSe $(n=8)$, R ASe $(n=10)$, and R HSe $(n=6)$. Ewes $(n=32)$ with female singleton fetuses from which fetal ovaries were collected were included in this study.

\section{Tissue collection and immunohistochemistry}

On day 135 of the pregnancy, fetal weight was recorded, and fetal ovaries were collected and weighed. One ovary was fixed in Carnoy's solution and the other ovary in $10 \%$ formalin solution, and after dehydration the ovaries were embedded in paraffin. The ovaries ( $n=6-10 /$ treatment) were sectioned (one section/ovary along the longitudinal axis) at $5 \mu \mathrm{m}$ and mounted onto a glass slide.

Detection of PCNA (a marker of proliferating cells) and factor VIII (a marker of endothelial cells and thus vascularization) was performed as previously described in Carnoy's fixed tissues (Grazul-Bilska et al. 2007, 2008). Briefly, ovarian tissue sections were deparaffinized, rehydrated, and incubated with $3 \% \mathrm{H}_{2} \mathrm{O}_{2}$ in methanol to eliminate endogenous peroxidase activity. Then, the sections were rinsed several times in PBS containing TritonX100 $(0.3 \%, \mathrm{vol} / \mathrm{vol})$ and treated for $20 \mathrm{~min}$ with PBS containing normal horse serum (3\%, vol/vol; $\mathrm{ABC}$ kit, Vector Laboratories, Burlingame, CA) to block non-specific binding of antibodies. The sections were incubated overnight at $4{ }^{\circ} \mathrm{C}$ in PBS containing a primary monoclonal mouse antibody against PCNA (1:500 dilution; MAB24R, Chemicon International, Temecula, CA, USA) or rabbit polyclonal antibody against factor VIII (1:100 dilution; Sigma). Primary PCNA or factor VIII antibodies were detected by using biotin-labeled secondary anti-mouse or anti-rabbit antibodies (Vector Laboratories) respectively, and the $\mathrm{ABC}$ method. For color development, SG substrate was used as described previously (Grazul-Bilska et al. 2007, 2008). For controls, the primary antibody was replaced with normal mouse $\operatorname{lgG}(4 \mu \mathrm{g} / \mathrm{ml})$ or rabbit serum. After immunostaining of PCNA, the tissue sections were counterstained with nuclear fast red to visualize nuclei.

To localize apoptotic cells in fetal ovarian sections fixed in formalin, TdT-FragEL, DNA fragmentation detection kit was used according to the manufacturer's protocol (Oncogene Research Products, San Diego, CA, USA). As a positive control, tissues sections from the corpora lutea undergoing luteolysis were used as described previously (Vonnahme et al. 2006).

\section{Image analysis}

For all ovaries, images of stained sections $\left(0.025 \mathrm{~mm}^{2}\right.$ per field) were taken for each of the four types of follicles (i.e., primordial, primary, secondary, and antral), for stromal tissue within medulla not containing follicles or blood vessels greater than $10 \mu \mathrm{m}$ in diameter, and for all visible blood vessels ( $>10 \mu \mathrm{m}$ in diameter) within medulla and hilus (total 5-30 images/ovary). The images were then used for quantitative image analysis using the Image Pro-plus software (Media Cybernetics Inc., Silver Spring, MD, USA) to determine the proportion $(\%)$ of proliferating primordial follicle of the total number of primordial follicles in the area, the LI for granulosa cells of the primordial and primary follicles, the LI for granulosa and theca cells of the secondary and antral follicles, stromal tissues, and blood vessels for the four treatment groups. The primordial follicle was considered as proliferating when at least one granulosa cell was PCNA-positive. For secondary and antral follicles, the $\mathrm{LI}$ was determined for granulosa and theca layers separately. The $\mathrm{LI}$ for thecal cells included all labeled 
Table 2 The number of primordial, primary, secondary, and antral follicles analyzed for each treatment group.

\begin{tabular}{lcccr}
\hline & \multicolumn{4}{c}{ Follicle type } \\
\cline { 2 - 5 } $\begin{array}{l}\text { Treatment } \\
\text { group }\end{array}$ & Primordial & Primary & Secondary & Antral \\
\hline M ASe & 699 & 83 & 120 & 144 \\
M HSe & 464 & 85 & 92 & 92 \\
R ASe & 542 & 105 & 142 & 54 \\
R HSe & 537 & 47 & 92 & 34 \\
Total number & 2242 & 320 & 446 & 325 \\
$\quad \begin{array}{l}\text { of follicles } \\
\text { analyzed }\end{array}$ & & & & \\
\hline
\end{tabular}

cells, and no attempt was made to distinguish between cell types within thecal layer. The number of primordial, primary, secondary, and antral follicles analyzed for each treatment group is presented in Table 2. For blood vessels, both endothelium and smooth muscle cell layers were analyzed together, and blood vessels were not classified as arterioles or venules. The $\mathrm{LI}$ was calculated as a percentage of proliferating cells out of the total cells per marked area of follicle, stromal tissue or blood vessel. Due to heterogeneous distribution of blood vessels within ovarian compartments, quantitation of factor VIII staining, and thus vascularization, using image analysis was not performed (Fig. 7).

\section{Statistical analyses}

Data are expressed as mean \pm s.E.M.. Data were analyzed as a completely randomized design with a $2 \times 2$ factorial arrangement of treatments using PROC GLM (SAS Inst. Inc., Cary, NC, USA 2005). The model contained effects for plane of nutrition (M and R), level of Se (ASe and HSe), and the plane of nutrition $\times \mathrm{Se}$ interactions. When the $F$-test was significant $(P<0.05$ or 0.1$)$, differences among means were evaluated by using the least square means procedure (Kirk 1982). Means were considered different when $P<0.05$ unless otherwise stated.

\section{Declaration of interest}

The authors declare that there is no conflict of interest that could be perceived as prejudicing the impartiality of the research reported.

\section{Funding}

This project was supported by USDA grants 2005-35206-15281 and 2006-38640-16858, NCR-SARE project GNC 06-062 and Hatch Project ND01712.

\section{Acknowledgements}

The authors would like to thank Mr James D Kirsch, Mr Kim C Kraft, Mr Robert Weigl, Mr Tim Johnson, Mr Terry Skunberg and other members of our laboratory for their technical assistance, and Ms. Julie Berg for clerical assistance. We would also like to acknowledge the valuable collaboration and assistance provided by Dr Bret Taylor and the US Sheep Experimental Station, Dubois, ID.

\section{References}

Augustin HG 2000 Vascular morphogenesis in the ovary. Baillieres Best Practice \& Research. Clinical Endocrinology \& Metabolism 14 867-882.

Barker DJ 2007 The origins of the developmental origins theory. Journal of Internal Medicine 261 412-417.

Baserga R 1985 The Biology of Cell Reproduction, Cambridge, MA: Harvard University Press.

Basini G \& Tamanini C 2000 Selenium stimulates estradiol production in bovine granulosa cells: possible involvement of nitric oxide. Domestic Animal Endocrinology 18 1-17.

Bodensteiner KJ, McNatty KP, Clay CM, Moeller CL \& Sawyer HR 2000 Expression of growth and differentiation factor-9 in the ovaries of fetal sheep homozygous or heterozygous for the inverdale prolificacy gene (FecX(I)). Biology of Reproduction 62 1479-1485.

Borwick SC, McMillen SR, Racey PA \& Rhind SM 1997 Effect of undernutrition of ewes from the time of mating on fetal ovarian development in mid gestation. Reproduction, Fertility, and Development $9711-715$

Bullejos M, Bowles J \& Koopman P 2002 Extensive vascularization of developing mouse ovaries revealed by caveolin-1 expression. Developmental Dynamics 225 95-99.

Byskov AG \& Westergaard LG 2004 Differentiation of the ovaries. In Fetal and Neonatal Physiology, pp 1941-1948. Eds RA Polin, WW Fox \& SH Abman. Philadelphia, PA: Elsevier, Saunders.

Carlson DB, Reed J, Borowicz PP, Taylor JB, Reynolds LP, Neville TL, Redmer DA, Vonnahme KA \& Caton JS 2008 Effects of dietary selenium supply and timing of nutrient restriction during gestation on maternal growth and body composition of pregnant adolescent ewes. Journal of Animal Science 87 669-680.

Clark LC, Combs GF, Turbull BW, Slate EH, Chalker DK, Chow J, Park LS, Sanders BB, Smith CL \& Taylor JR 1996 Effect of selenium supplementation for cancer prevention in patients with carcinoma of the skin. Journal of the American Medical Association 276 1957-1962.

Combs GF Jr 2001 Considering the mechanisms of cancer prevention by selenium. Advanced Experimental Medical Biology 492 107-117.

Combs GF \& Lu J 2001 Selenium as a cancer preventive agent. In Selenium: Its Molecular Biology and Role in Human Health, pp 219-234. Ed. DL Hatfield. Norwell, MA: Kluwer.

Erickson GF 2001 Role of growth factors in ovary organogenesis. Journal of the Society for Gynecologic Investigation 8 S13-S16.

Fowler PA, Dorà NJ, McFerran H, Amezaga MR, Miller DW, Lea RG, Cash P, McNeilly AS, Evans NP, Cotinot C, Sharpe RM \& Rhind SM 2008 In utero exposure to low doses of environmental pollutants disrupts fetal ovarian development in sheep. Molecular Human Reproduction 14 269-280.

Fraser HM 2006 Regulation of the ovarian follicular vasculature. Reproductive Biology and Endocrinology 418.

Ganther HE 1999 Selenium metabolism, selenoproteins and mechanisms of cancer prevention: complexities with thioredoxin reductase. Carcinogenesis 20 1657-1666.

Gardner DS, Lea RG \& Sinclair KD 2008 Developmental programming of reproduction and fertility: what is the evidence? Animal 2 1128-1134.

Gaytan F, Morales C, Bellido C, Aguilar E \& Sanchez-Criado JE 1996 Proliferative activity in the different ovarian compartments in cycling rats estimated by the 5-bromodeoxyuridine technique. Biology of Reproduction 54 1356-1365.

Gougeon A 2004 Dynamics for human follicular growth: morphologic, dynamic and functional aspects. In The Ovary, pp 25-43. Eds PKC Leung \& EY Adashi. New York: Elsevier, Academic Press.

Grazul-Bilska AT, Redmer DA \& Reynolds LP 2001 Growth factors during ovarian angiogenesis. In Vascular Morphogenesis in the Female Reproductive System, pp 131-147. Eds H Augusitin, L Ituela-Arispe, $P$ Rogers \& S Smith. Boston: Springer Verlag.

Grazul-Bilska AT, Navanukraw C, Johnson ML, Vonnahme KA, Ford SP, Reynolds LP \& Redmer DA 2007 Vascularity and expression of angiogenic factors in bovine dominant follicles of the first follicular wave. Journal of Animal Science 85 1914-1922.

Grazul-Bilska AT, Banerjee J, Yazici I, Borowczyk E, Bilski JJ, Sharma RK, Siemionov M \& Falcone T 2008 Morphology and function of cryopreserved whole ovine ovaries after heterotopic autotransplantation. Reproductive Biology and Endocrinology 616. 
Van der Hurk R \& Zhao J 2005 Formation of mammalian oocytes and their growth, differentiation and maturation within ovarian follicles. Theriogenology 63 1717-1751.

Jablonka-Shariff A, Fricke PM, Grazul-Bilska AT, Reynolds LP \& Redmer DA 1994 Size, number, cellular proliferation and atresia of gonadotropininduced follicles in ewes. Biology of Reproduction 51 531-540.

Jablonka-Shariff A, Reynolds LP \& Redmer DA 1996 Effects of gonadotropin treatment and withdrawal on follicular growth, cell proliferation, and atresia in ewes. Biology of Reproduction 55 693-702.

Jiang C, Jaing W, Ip C, Ganther H \& Lu J 1999 Selenium- induced inhibition of angiogenesis on mammary cancer at the chemopreventative levels of intake. Molecular Carcinogenesis 26 213-225.

Juengel JL, Sawyer HR, Smith PR, Quirke LD, Heath DA, Lun S, Wakefield SJ \& McNatty KP 2002 Origins of follicular cells and onthogeny of steroidogenesis in ovine fetal ovaries. Molecular and Cellular Endocrinology 191 1-10.

Kirk RE 1982 Experimental Design: Procedures for the Behavioral Sciences, 2nd edn. Belmont, CA: Brooks/Cole.

Lea RG, Andrade LP, Rae MT, Hannah LT, Kyle CE, Murray JF, Rhind SM \& Miller DW 2006 Effects of maternal undernutrition during early pregnancy on apoptosis regulators in the ovine fetal ovary. Reproduction 131 113-124.

Lundy T, Smith P, O'Connell A, Hudson NL \& McNatty KP 1999 Populations of granulosa cells in small follicles of the sheep ovary. Journal of Reproduction and Fertility 115 251-262.

Luther JS, Redmer DA, Reynolds LP \& Wallace JM 2005 Nutritional paradigms of ovine fetal growth restriction: implications for human pregnancy. Human Fertility 8 179-187.

Luther J, Aitken R, Milne J, Matsuzaki M, Reynolds L, Redmer D \& Wallace J 2007 Maternal and fetal growth, body composition, endocrinology, and metabolic status in undernourished adolescent sheep. Biology of Reproduction 77 343-350.

McIntush EW \& Smith MF 1998 Matrix metalloproteinases and tissue inhibitors of metalloproteinases in ovarian function. Reviews of Reproduction 3 23-30.

McNatty KP, Fidler AE, Juengel JL, Quirke LD, Smith PR, Heath DA, Lundy T, O'Connell A \& Tisdall DJ 2000 Growth and paracrine factors regulating follicular formation and cellular function. Molecular and Cellular Endocrinology 163 11-20.

Murdoch WJ, Van Kirk EA, Vonnahme KA \& Ford SP 2003 Ovarian responses to undernutrition in pregnant ewes, USA. Reproductive Biology and Endocrinology 16.

Nathanielsz PW 2006 Animal models that elucidate basic principles of the developmental origins of adult diseases. ILAR Journal 47 73-82.

Neville TL, Ward MA, Reed JJ, Soto-Navarro SA, Julius SL, Borowicz PP, Taylor JB, Redmer DA, Reynolds LP \& Caton JS 2008 Effects of level and source of dietary selenium on maternal and fetal body weight, visceral organ mass, cellularity estimates, and jejunal vascularity in pregnant ewe lambs. Journal of Animal Science 86 890-901.

NRC 1985 Nutrient Requirements of Sheep, 6th edn. Washington, DC: National Academy Press.

Osgerby JC, Wathes DC, Howard D \& Gadd TS 2002 The effect of maternal undernutrition on ovine fetal growth. Journal of Endocrinology 173 131-141.

Parshad RK 1999 Effects of selenium toxicity on oestrous cyclicity, ovarian follicles, ovulation and foetal survival in rats. Indian Journal of Experimental Biology 37 615-617.

Pepe GJ, Billiar RB \& Albrecht ED 2006 Regulation of baboon fetal ovarian folliculogenesis by estrogen. Molecular and Cellular Endocrinology 247 41-46.

Qi A, Zhang Z, Cao G \& Zhang Y 2008 Histological study of germ cells development and apoptosis in mongolian sheep fetal ovaries. Animal Reproduction Science 103 179-186.

Rae MT, Palassio S, Kyle CE, Brooks AN, Lea RG, Miller DW \& Rhind SM 2001 Effect of maternal undernutrition during pregnancy on early ovarian development and subsequent follicular development in sheep fetuses. Reproduction 122 915-922.

Redmer DA \& Reynolds LP 1996 Angiogenesis in the ovary. Reviews of Reproduction 1 182-192.
Redmer DA, Wallace JM \& Reynolds LP 2004 Effects of nutrient intake during pregnancy on fetal and placental growth and vascular development. Domestic Animal Endocrinology 27 199-217.

Reed JJ, Ward MA, Vonnahme KA, Neville TL, Julius SL, Borowicz PP, Taylor JB, Redmer DA, Grazul-Bilska AT, Reynolds LP et al. 2007 Effects of selenium supply and dietary restriction on maternal and fetal body weight, visceral organ mass and cellularity estimates, and jejunal vascularity in pregnant ewe lambs. Journal of Animal Science 85 2721-2733.

Rhind SM, Rae MT \& Brooks AN 2003 Environmental influences on the fetus and neonate - timing, mechanisms of action and effects on subsequent adult function. Domestic Animal Endocrinology 25 3-11.

Robinson LL, Sznajder NA, Riley SC \& Anderson RA 2001 Matrix metalloproteinases and tissue inhibitors of metalloproteinases in human fetal testis and ovary. Molecular Human Reproduction 7 641-648.

Salbe AD, Albanes D, Winick M, Taylor PR, Nixon DW \& Levander OA 1990 The effect of elevated selenium intake on colonic cellular growth in rats. Nutrition and Cancer 13 81-87.

Sawyer HR, Smith P, Heath DA, Juengel JL, Wakefield SJ \& McNatty KP 2002 Formation of ovarian follicles during fetal development in sheep. Biology of Reproduction 66 1134-1150.

Da Silva P, Aitken RP, Rhind SM, Racey PA \& Wallace JM 2002 Impact of maternal nutrition during pregnancy on pituitary gonadotrophin gene expression and ovarian development in growth-restricted and normally grown late gestation sheep fetuses. Reproduction 123 769-777.

Da Silva P, Aitken RP, Rhind SM, Racey PA \& Wallace JM 2003 Effect of maternal overnutrition during pregnancy on pituitary gonadotrophin gene expression and gonadal morphology in female and male foetal sheep at day 103 of gestation. Placenta 24 248-257.

Statistical Analysis System Institute 2005 SAS: User's Guide, Statistics, 5th edn. Cary, NC, USA: Statistical Analysis System Institute.

Tanaka Y, Moriyoshi M, Nadaka K \& Sawamukai Y 2001 Appearance and number of follicles and change in the concentration of serum $\mathrm{FSH}$ in female bovine fetuses. Reproduction 121 777-782.

Vonnahme KA, Redmer DA, Borowczyk E, Bilski JJ, Luther JS, Johnson ML, Reynolds LP \& Grazul-Bilska AT 2006 Vascular composition, apoptosis, and expression of angiogenic factors in the corpus luteum during prostaglandin $\mathrm{F}_{2 \alpha}$-induced regression in sheep. Reproduction 131 1115-1126.

Wandji SA, Pelletier G \& Sirard MA 1992 Ontogeny and cellular localization of 125I-labeled insulin-like growth factor-I, 125I-labeled follicle-stimulating hormone, and 125l-labeled human chorionic gonadotropin binding sites in ovaries from bovine fetuses and neonatal calves. Biology of Reproduction 47 814-822.

Wright C, Evans AC, Evans NP, Duffy P, Fox J, Boland MP, Roche JF \& Sweeney T 2002 Effect of maternal exposure to the environmental estrogen, octylphenol, during fetal and/or postnatal life on onset of puberty, endocrine status, and ovarian follicular dynamics in ewe lambs. Biology of Reproduction 67 1734-1740.

Wu G, Bazer FW, Wallace JM \& Spencer TE 2006 Board-invited review: intrauterine growth retardation: implications for the animal sciences. Journal of Animal Science $\mathbf{8 4} 2316-2337$.

Yeh JY, Ou BR, Liang YC, Burchfiel J, Butler J, Forsberg N \& Whanger P 2006 Mechanism for proliferation inhibition by various selenium compounds and selenium-enriched broccoli extract in rat glial cells. Biometals 19 611-621.

Zeng H 2002 Selenite and selenomethionine promote HL-60 cell cycle progression. Journal of Nutrition 132 674-679.

Zeng H \& Combs GF Jr 2008 Selenium as an anticancer nutrient: roles in cell proliferation and tumor cell invasion. Journal of Nutritional Biochemistry 19 1-7.

Received 2 September 2008

First decision 23 October 2008

Revised manuscript received 16 December 2008

Accepted 7 January 2009 